\title{
Peculiarities of Corruption in Russia and the Challenges Involved
}

\author{
N. A. Simonia ${ }^{1}$
}

In the overwhelming majority of cases, analyses of the current corruption problem in Russia suffer from the same main methodological delusion. Corruption is regarded from the standpoint of the current experience in firmly established and highly developed Western countries. In fact, the main peculiarity of corruption in Russia is its close connection with two important historic processes.

First, corruption is closely connected to the "primitive accumulation" process. Contrary to Europe's historic past, where the fruits of "primitive accumulation" of capital were mainly used within a given national framework, the lion's share of capital derived from activities within the Russian state is flowing out to off-shore zones and to the West.

Second, the process of capital formation is not normal, but can instead be called "bureaucratic capitalism"- a synthesis in which bureaucracy and business are extremely closely intertwined. In pre-war Japan and post-war South Korea, bureaucracy also initiated large-scale capital formation, but was separated from business and strictly controlled by a strong central power. In Russia, due to the weakness of the central government, the bureaucracy found itself completely emancipated, and bureaucratic capital accumulation acquired a rapacious and parasitic nature (similar to conditions in Indonesia in the 1950's and 1960's during the first term of President Sukarno).

The main mechanism of bureaucratic capital formation was not a well-thought through and purposeful national economic policy (as it was in the Japanese and Korean cases), but the corruption of the top levels of bureaucracy which, branching out like cancer metastases, enveloped the major part of society in a few years and turned into the "way of life". ${ }^{2}$ Here it is important to understand that the main question is not about traditional corruption, which is also widespread in Russia, in which businessman A bribes official B to acquire benefits, avoid taxes, obtain state orders, and so on, thereby damaging both state and society. In Russia, A and B participate in one and the same business, at the expense of the state. Meanwhile, the Russian experience shows that A and B can exchange places, and sometimes

\footnotetext{
${ }^{1}$ N.A. Simonia is the Deputy Director of the Institute of World Economics and International Relations and a Member of the Russian Academy of Sciences.

${ }^{2}$ For details on the interconnection between corruption and bureaucratic capital, see N. Simonia, "On Bureaucratic capitalism in Russia," World Economy and International Relations 7 (1996): 5-6; and N. Simonia, "Peculiarities of National Corruption," Svobodnaya Mysl 21:7 (2001): 416 , and $21: 8,19-24$.
} 


\section{THE QUARTERLY JOURNAL}

even take on both roles simultaneously in spite of legislative prohibitions against such combination. ${ }^{3}$

In the last ten years, three levels of bureaucratic capital formation and three types of corruption have been established in Russia: general-federal (or "oligarchic"), regional-municipal (or "governor's"), and director-managerial (on the level of separate enterprises). Below these levels, at the same time, on the "ground floor" of society, traditional forms of corruption take place on a mass basis, and some segments cooperate quite closely with the "top floors" (especially the second and third types), and may even be integrated into them as an auxiliary component. As a result of these conditions, the organized forms of corruption and criminality that have been established have frequently been used by top officials in competition with one another, and even in the political struggle. The concept of a "roof" that Russian citizens have grown accustomed to has begun to transform.

Usually the idea of a "roof" is interpreted as the cover protecting the business operations of one criminal group from encroachment by other criminal groups. Today, however, this concept has acquired a wider and deeper meaning. It already includes corrupt officials and law-enforcement agencies. Practically every business nowadays begins with the establishment of a "roof," and not with the foundation - the business itself. Only after having established all of the necessary connections can one start to conduct business.

The wide-scale and all-embracing corruption in Russia has led to the most negative consequences for the country, the full range of which we are unable to dwell upon here. It is necessary, however, to enumerate some of the most important of them.

First, the very ideas of economic reform and the democratization of society have been discredited. The problem is not only that the destruction of old socioeconomic structures was carried out in a landslide manner, without preliminary institutional reforms and the appropriate legislative infrastructure. Much worse is the fact that, having gained political power, Russian reformers adapted themselves to the processes of bureaucratic capital formation and even integrated themselves into them. As a result, almost all of the market institutions that, in form, they borrowed from the West, in practice appeared to be filled with indigenous content that promoted flourishing criminality and corruption. The majority of laws and resolutions adopted from 1992-1997 contained all the necessary loopholes for the above to occur. Instead of leading to liberalization and democratization, privatization led to a narrow oligarchic monopolization founded on corruption existing beyond any legal boundaries.

\footnotetext{
${ }^{3}$ According to information from the Ministry of Internal Affairs, between 1994 and mid-1997, more than 800 cases of such violations were revealed. "Russia vs. Corruption: Who wins?" Analytic report by the Council on Foreign and Defense Policy and INDEM Foundation, Moscow, 1998, p. 31.
} 
A second consequence has been that the social differentiation of society has sharply increased. Even according to official data, about 40 percent of the population now exist below the poverty line, while the minimum salary has not yet reached the level of the official minimum living standard. An income gap between the richest ten percent and the poorest ten percent of the population has been constantly increasing during the course of the "reforms." In the difficult year of 1992, the richest tenth possessed eight times more wealth than the poorest tenth, while in 1998 (before the financial crisis) they possessed 13.3 times more. ${ }^{4}$ Due to the monopoly of bureaucratic capital and the corruption of officials, no mass middle class was able to emerge; such a class is the basis of civil society and political democracy in modern society. The number of small businessmen in Russia over the course of the 1990s stagnated at around 900,000, while their share of GDP amounted to only 3 percent. The share of tax proceeds to the budget from small business in Russia does not exceed ten percent, while in Europe this indicator is more than 50 percent. ${ }^{5}$ Generally speaking, the opportunities for free private enterprise turned out to be extremely limited. Profiting from the weakness and inertness of the central government, officials took all types of business activity under strict control. This led to the complete marginalization of non-bureaucratic capital, which departed to the shadow economy, as a result of which financial flows were not registered in any way and thus could not be collected by tax authorities. Recent research carried out by the Social Center of the Russian Academy of State Service demonstrated that the shadow economy accounts for around US\$50-60 billion. ${ }^{6}$

A third threat to the economic and social security of Russia connected with the predominance of corrupt bureaucratic capital and a general worsening of the economic situation lies in the massive drain of capital and knowledge from the country. According to existing estimates, the illegal outflow of capital from Russia between 1994 and 2000 amounted to about US\$120 billion? Pricewaterhouse Coopers estimates that because of the direct and indirect action of bureaucratic capital (through lobbying in executive and legislative bodies of power), the country faces an annual deficit of US $\$ 9.8$ billion in direct foreign investment. ${ }^{8}$ As of the end of 2000, the volume of direct investment accumulated in the years of reform totaled only US $\$ 17.2$ billion or, put another way, US\$120.6 per capita. The ratio of direct investment to GDP between 1992-1999 averaged 0.2 per cent-

\footnotetext{
${ }^{4}$ Goskomstat, Monthly Bulletin on the Social and Economic Situation in Russia, JanuarySeptember 1998. 237.

${ }^{5}$ Joseph R. Blashi, Maya Kroumova, and Douglas Kruse, Kremlin Capitalism. The Privatisation of the Russian Economy (Ithaca: Cornell University Press, 1997), 26; Vedomosty, 22 February 2001; Kommersant, 10 August 2001.

${ }^{6}$ Nezavisimaya Gazeta, 20 June 2001.

${ }^{7}$ Policy of Attraction of Direct Investments to Russian Economy. (Bureau of Economic Analysis). Moscow, 2001, 19.

${ }^{8}$ Vedomosty, 25 April 2001.
} 


\section{THE QUARTERLY JOURNAL}

one of the lowest indicators among 21 countries with developing and transitional economies. ${ }^{9}$ At the same time, in trying to compensate for the damage caused by the self-serving activity of bureaucratic capital towards state finance, all Russian governments up until the 1998 financial crisis borrowed considerable sums from international financial organizations and on the eurobonds market to support the budget, which led to headlong debt growth.

A fourth consequence of the unrestrained pursuit of quick enrichment has been that the top tier of bureaucratic capital has concentrated its activity on exportoriented and extractive raw material industries, especially those connected with energy. A paradox of this situation lies in the fact that whole regions of Russia systematically suffer from shortages of fuel and raw materials in a country that is one of the richest in energy resources. In the 1990s, there appeared an obvious tendency for the country to turn into a raw material adjunct of the developed world.

A fifth consequence of the swelling of regional bureaucratic capital was that its increasing opposition to a weak federal center created the potential peril of disintegrative processes, threatening the integrity of Russian statehood. Especially dangerous were the development of those tendencies in outlying districts of the country to the west, east and south of the center. All this happened against the background of a considerable breakdown of the defense complex and a decline in and demoralization of the armed forces. Corruption in the bureaucratic leadership of the armed forces combined with real under-financing of the army to create a situation whereby exports of arms and technologies-at times including systems not yet available to the Russian armed forces-took place to countries both near and far, contributing an additional military threat to the security of the country.

The demoralizing influence of large-scale corruption practically paralyzed the activities of law-enforcement agencies, having created a threat to the internal security of the country. In fact, a distortion of the main function of those bodies took place. Instead of protecting citizens and property, they found themselves in the service of bureaucratic capital, and gradually became involved in corruption and criminal activity. It can be stated without any exaggeration that the situation in some regions of the country began to resemble a state of existence beyond any legal boundaries and of complete lawlessness that has been seen in a number of countries in sub-Saharan Africa in recent years.

The first real, though timid, attempt to place a barrier in the way of a further expansion of corruption was made by the government of Yevgeni Primakov. However, the corrupt bureaucracy and oligarchs, leaning on support from the group around president Boris Yeltsin known as the "Family," managed to insist upon the resignation of Primakov. A more planned, systematic, and steadfast attack on the position of bureaucratic capital on all levels was only begun after Vladimir

\footnotetext{
${ }^{9}$ Policy of Attraction of Direct Investments, op. cit., 39, 46.
} 
Putin came to power, especially after his election as president. A precondition for any effective fight with corruption is a broad front of institutional reforms to create a strong, high-quality state apparatus that would be able to transform, as the initial step, the Indonesian version of bureaucratic capital into some variety of a Japanese or South Korean one (with the prospect of its subsequent rapprochement with Western models), to protect small and medium-sized businesses, to regulate the activities of natural resource monopolies, and to provide social, legal, economic, and foreign security for the country.

President Putin has the indisputable advantage of irrefutable popularity and enjoys the confidence of a large part of the country's population, though the former can decrease in the course of implementing liberal reforms. On the other hand, a no less important negative factor, able to seriously hamper if not to ruin his initiatives, are his genetic ties to the "Family," which pushed him forward in his political career and practically brought him to power. Putin has to act extremely cautiously, and without undue haste. Putin's getting out from under the influence of the "Family" is one of the main preliminary conditions for the success of Russia's reform. Nevertheless, in the last year and a half Putin managed to do quite a lot. In this article there is no chance to dwell on all the details of his achievements, many of which are still at the initial stage of realization. There is a chance to enumerate only the most important and apparent of them.

\section{The taming of "oligarchs."}

To do away with the practices of the Yeltsin period, when oligarchs competed with each other for influence upon the President and membership in the "Family," Putin from the very beginning proclaimed his policy of "equal remoteness" from all oligarchs. The main goal of that policy was to separate oligarchs from state politics and from the state decision-making process. It is important to understand (especially for those Westerners who tend to believe information in the press about the restoration of Soviet order) that Putin is not against capital, including large capital formations. He is simply striving for a transformation of Russian business so that businessmen pay taxes in full and on time, do not seek illegal benefits and indulgences during tenders and while obtaining state orders, and so on. His credo is that a businessman should be engaged in business and not in politics. Thus, it is not by chance that the first to come under fire from state bodies were the most ambitious and politically active oligarchs-Berezovsky and Gusinsky - who, beside other things, possessed vast mass media empires. As for other oligarchs (LUKOIL, Interros, RAO "EEC", Avtovaz, and many others), the tactic of preventive action was used: interrogation in law-enforcement agencies, audit of financial documents by tax inspectors, the Accounting Chamber, and others. At his very first meeting with big business representatives that took place in July 2000, at their request, Putin made it quite clear to his interlocutors that he 


\section{THE QUARTERLY JOURNAL}

had no intention to build relations with them on the personal basis they had formerly been accustomed to, but intended to discuss general corporate problems of a financial and economic nature only with representatives of organized business. The meeting was taken as an effort to display the President's complete superiority over the invited oligarchs. As the press stressed, commenting on the above meeting, Putin deprived them of a political vote and reduced them to the status of businessmen. ${ }^{10}$ The signal was understood, and in August 2000 all oligarchs together joined the Russian Union of Industrialists and Entrepreneurs (RUIE), headed by Arkady Volsky. Two subsequent meetings with the President (in January and May 2001) took place exactly within this given framework. ${ }^{11}$ In the course of these meetings, the President practically began to act as the supreme arbitrator between large business and government bureaucracy.

The second most significant event in the examined period was the dismissal of Rem Vyakhirev from the post of leader of Gazprom, the organization regarded as a state within the state, which provided up to twenty percent of the revenue of the Russian budget. Having placed Alexei Miller in the top post at Gazprom, his own protégé and a person not connected with any oligarchic clan or political group, Putin delivered a serious blow to one of the largest arenas of corruption. According to available information, Miller has already made a decision to deny the Itera company the rights to sell Russian gas. This private intermediary company was created by Gazprom in the mid-1990s and has become the principal channel for money laundering and the withdrawal of large assets from Gazprom. Gas was sold to Itera at cost, then exported and sold at market prices. Assets, affiliated companies, and deposits were given to Itera at ridiculously low prices. According to some estimates, up to US\$10 billion escaped from Russia annually through Gazprom channels. ${ }^{12}$

Putin's offensive on natural resource monopolies has not been limited to the pinpoint (albeit large-scale) strike against Gazprom. Institutional preparations for more complete control over large corporations are being made. This is reflected, in particular, in the decision to create a new institution-the Joint Tariff Bodythat will be given control over all natural resource monopolies. Anatoly Chubais (RAO "EEC") has made efforts aimed at creating this body on the basis of German Gref's Ministry of Economics. The former supports Chubais' variant of reforms in RAO "EEC." Putin has chosen the Federal Energy Commission (FEC) as the basis for the new body, which is regarded as a serious defeat of Chubais ${ }^{13}$ In addi-

\footnotetext{
${ }^{10}$ Segodnya, 25 January 2001.

${ }^{11}$ Vedomosty, 20 February 2001 and July 2001; Nezavisimaya Gazeta, 25 January and 20 February 2001; Izvestiya, 1 June 2001.

12 Much has been published about corruption schemes connected with Russian gas. Revealing articles include Novaya Gazeta, 6-8, 23-26, and 26-28 August 2001; Moskovsky Komsomolets, 18 August 2001; Profil, No.2, 14 June 2001, pp.4-6, 12-13.

${ }^{13}$ Kommersant, 7 August 2001.
} 
tion, specialized inspection of the largest taxpayers has been implemented under the Ministry of Tax Service. It is already known that LUKOIL, Gazprom, and other corporations will be among the first to be transferred for registration under this inspection. ${ }^{14}$ Finally, the newly appointed head of the Ministry of Energy, Igor Jusufov, has already declared that his ministry will once again take over the function of distributing oil export volumes, while only extractive companies will get access to export pipelines. All of the mediator firms and ephemeral companies created for the purpose of laundering offshore "dirty money" will be removed from the scene. ${ }^{15}$ The above, plus many other measures already taken or planned, will undoubtedly result in a considerable decrease in the scale of corruption and its most odious manifestations.

\section{Strengthening Russian Statehood: Attacking Regional Bureaucratic Capital.}

After landslide privatization left most industrial enterprises in the hands of former directors ("insiders"), Russian reformers hoped that the insiders would soon be ousted by "outsiders" (meaning mainly businessmen from Moscow or elsewhere, with foreign capital) through the operation of the market. These calculations were only partly justified, and even then not always with positive results. With market institutions either absent or with shallow roots, a rapprochement and, in a number of cases, a coalition took place between insiders and the local bureaucracy, forming regional bureaucratic capital. ${ }^{16}$ The dependence of local business on local power is much stronger, as a rule, than on central power. Governors decide whether to grant this or that bank the right to serve the accounts of the treasury and various regional programs and establish preferential tariffs for electricity and transport or other utilities. In practical terms, governors controlled local lawenforcement agencies, as well as the tax service and arbitration courts, for example. Along with other factors, regional corruption promoted centrifugal tendencies, threatening the consolidation of Russian statehood. Under these conditions it is no wonder that one central question confronting Putin during the previous period turned out to be how to block those centrifugal tendencies.

One of the first steps of the President was Decree No. 849 of 13 May 2000 that introduced Plenipotentiary presidential representatives (PPR) in seven newlyformed federal districts. The main responsibilities of the PPR were: local coordination of the activity of federal executive bodies, control over execution of decisions from the federal government, working out socioeconomic development pro-

\footnotetext{
${ }^{14}$ Vedomosty, 24 August 2001.

${ }^{15}$ Kommersant, 15 August 2001.

${ }^{16}$ In the struggle waged for re-division of property, governors usually backed their own insiders against alien (Russian and foreign) owners, using arbitrary courts subordinate to them for pronouncing decisions on the "bankruptcy" of profitable enterprises, re-nationalization, etc. See Transition (The World Bank/The William Davidson Institute Newsletter) 5 (August-Sept.-Oct. 2000): 36-37.
} 


\section{THE QUARTERLY JOURNAL}

grams in the federal districts, and introducing proposals (to be considered by the President) to terminate the effect of local acts at variance with the federal Constitution, federal laws, and Russia's international obligations. President Putin's next step was aimed at undermining the positions of governors in the upper chamber of the Parliament - the Council of Federation. The process of exchanging them for regional representatives appointed by governors was begun, a process due to be completed by January 2002. ${ }^{17}$ These representatives will work in Moscow on a permanent basis, and will be dependent both materially and for their career on decisions of the President. (No wonder that they have already formed a group called "Federation" to support presidential initiatives.) By mid-March 2001, 100 of 179 senators had joined this group. ${ }^{18}$ In July 2000, the Duma passed a law granting the President the right to dismiss governors in cases where legal proceedings had been initiated against them. In order to exclude the possibility for heads of regional administrations to evade this provision through pre-term resignation and subsequent nomination of their candidates, the Duma passed a legislative amendment forbidding both this and the repeated nomination of candidates by heads of administration dismissed by the President. ${ }^{19}$

The second wave of reforms began in May-June 2001, when a special presidential committee was formed, headed by the deputy head of the presidential administration, Dmitry Kozak, on the differentiation of authority between the center and the regions. Its aim was to limit (and even abolish) the privileges received by republics and regions in agreements signed with President Yeltsin. Putin himself headed the first meeting of the committee on 17 August 2001. The main aim of the committee was the restoration of a single legal space in the country and the elimination of much discretionary spending by governors. ${ }^{20}$ Moscow made it clear to leaders of subsidized regions that if they were not able to implement their budget responsibilities, control over spending might pass to the federal treasury (which could mean a range of things, from the introduction of outside management up to discharging the governor from power). The PPR also received stronger powers, the most important of which in the context of this paper is the "re-subordination" of top officials of regional law-enforcement agencies to the local PPR and through them to the President. Appointment of these officials would from now on be made by the President based on a recommendation of the PPR and without needing agreement from regional governors. The latter would be merely informed about the appointments. ${ }^{21}$

All these changes are directed at converting federal agencies in the provinces from weapons of struggle used by local groups and elites into instruments of con-

\footnotetext{
${ }^{17}$ Expert 24 (25 June 2001),57.

18 Segodnya, 23 February 2001.

${ }^{19}$ Vedomosty, 27 February 2001.

${ }^{20}$ Vremya Novostei, 26 June 2001; Kommersant, 18 July 2001.

${ }^{21}$ Vremya Novostei, 28 June 2001; Vedomosty, 20 July 2001.
} 
trol over the financial, administrative, and other activities of the regional and republican authorities. These measures marked the beginning of halting the process of the erosion of statehood, and the beginning of managing the country. Without this process, any struggle with corruption would have remained just an empty phrase.

\section{Strengthening Russian Statehood: Reorganization of power structures.}

Experience bears witness to the fact that corruption cannot be abolished only with methods based on force. The deep economic roots of corruption (to say nothing about psychology and traditions) also need to be addressed. However, the presence of strong and disciplined law-enforcement agencies and other power structures is a necessary preliminary condition to make it possible to start the struggle with the many manifestations of corruption. That is why one of the top priorities of President Putin was to restore the functionality of power structures and suppress their increasing involvement in criminal activity. March 2001 was a turning point here, when Putin discharged the leaders of law-enforcement agencies and appointed new people loyal to him, who were not connected with old competing groups. Representatives of the Yeltsin "old guard" were also squeezed out, including the head of the Ministry of the Interior, Vladimir Rushailo, the head of the Federal Tax Police Service (FSTP), Vyacheslav Soltaganov, the leader of the Ministry of Atomic Energy, Yevgeny Adamov, and others.

The appointment of a civilian, Boris Gryzlov, as head of the Ministry of Interior in April 2001 was a surprise to everyone. Then came the replacement of practically the whole leadership of the Ministry. However, most important was the reorganization of the Ministry, which numbers around one million employees and had branched into multiple parallel structures that duplicated each other and were engaged in "covering" business, supported various business groups in competition with others and, finally, directly participated in business itself.2 Matters took a turn towards a completely uncontrollable situation and anarchy. On 4 June, Putin issued a decree on reform in the Ministry of Interior. Bearing in mind the aspect of corruption, the main change here lies in the liquidation of the Federal Committee of Criminal Police, created by Rushailo, that included agencies on the struggle with organized crime (UBOPs) and economic crimes (UBEPs) and the super secret "P" agency (dedicated to the struggle against "high-tech" crimes).

\footnotetext{
${ }^{22}$ Interior Minister B. Gryzlov himself pointed at all these moments in many speeches and interviews (see Vedomosty, 11 July 2001; Profil, 22 (11 June 2001), p. 8, and 23 (18 June 2001), pp. 14-16; Vremya Novostei, 27 July and 9 August 2001; Expert 22 (11 June 2001), p. 6; Kommersant, 31 July and 9 August 2001; Izvestiya, 9 August 2001. Among the population, the conviction began to take root that there was no great difference between the militia and criminal elements. Among bandits. a popular proverb emerged: "Only the 'shablovskie' are tougher than the 'solntsevskie." The "solntsevskie" is one of the mafia groups in Moscow and its region, while the central office of RUBOP - the regional agency for the fight against organized crime - is located on Shablovka Street.
} 


\section{THE QUARTERLY JOURNAL}

The agency turned out to be involved in providing information services to big business and using illegally-obtained information for blackmail and extortion. ${ }^{23}$ The agency will be reorganized into an operative investigation bureau, and will be included in the newly created Service of Criminal Police.

Additional changes touched upon other power structures connected in one way or another with financial and economic corruption. Another civilian, Michail Fradkov, was appointed as head of the Federal Service of Tax Police. At the end of June 2001, all seven of his deputies were dismissed and following a restructuring of the service, its central apparatus will concentrate on analytical work (i.e., it will no longer be directly engaged in any operational or enforcement activities). ${ }^{24}$ There are plans under development to increase the Accounting Chamber's status to the level of a body directly subordinate to the President as the main controller over state expenditure; the appropriate bill has already been introduced to the Duma. ${ }^{25}$ The leadership of the State Investment Corporation has been changed and a different Director General of the Committee on state reserves has been appointed. There was a change of leadership at the military-technical cooperation agency, while the agency itself underwent another restructuring. In a word, the wind of change touched upon all departments connected with financial flows, around which serious corruption scandals had spread in the recent past.

\section{Deregulation or Anti-bureaucratic Laws.}

In July 2001, during the last days of the work of the Russian Parliament before its summer vacation, a package of laws that had been initiated in Spring 2000 by President Putin was finally adopted. It included three laws relevant to the present discussion. First was a law on the registration of juridical persons and businessmen. Under the previous law, one had to gather dozens and even hundreds of signatures over a course of months (for bribes, of course). From 1 January 2002, the whole process will be accomplished in a single procedure managed by the Ministry of Taxes and Dues, and to be completed in the course of several days. Second came a law on the protection of juridical persons and businessmen during state audit. Audits will take place over the course of two months and not more often than once a year. Previously, audits could occur several times a year. Third was a law on licensing of various types of business activity. Of 500 federal and about 1000 regional types of licensing, only around 120 will remain. The process of adopting the last law was especially difficult, both in the government itself and in the Council of Federation, since the right to grant licenses was a source of enormous profits for regional administrations and ministries. ${ }^{26}$ Implementation of

\footnotetext{
${ }^{23}$ Moskovsky Komsomolets, 27 June 2001; Kommersant, 17 August 2001.

${ }^{24}$ Vremya Novostei, 4 July 2001.

${ }^{25}$ Vremya Novostei, 26 June 2001; Kommersant, 17 August 2001.

${ }^{26}$ According to the available estimations, the annual sum collected by ministries fluctuated in between 170-200 billion rubles (Profil28 (23 July 2001), p.18; Segodnya, 3 March 2001;).
} 
these laws would mean a real revolution in the establishment of Russian business, and will truly liberalize medium and small business.

Implementation will require a level of cooperation between President Putin and the Russian Government that has not yet been achieved. A clear example is the passage of the package of bills on the reduction of bureaucracy. Putin set this goal before the Government in Spring 2000, but by the autumn he found out that nothing had been accomplished, and demanded that the assignment be executed by January, and yet again by March 2001. The Government introduced the package to the Duma in April, after which several ministries lobbied against passing the proposed bill on licensing. ${ }^{27}$ In another example, the government of Yevgeny Primakov managed to pass 22 amendments to the law on production sharing agreements (PSA) in 1998 (after several years of procrastination). In the summer of 2000, Minister of Economy German Gref and Minister of Finance Kudrin, both reputed to be great liberals, started a campaign against that vitally important form of investments. When Putin voiced his support of PSA, Gref instantly changed his position. However, it turned out later that this change was temporary. In April-May 2001, Gref and Kudrin resumed their attacks, and today they are trying to introduce amendments into the appropriate chapter of the Tax Code that will emasculate the essence of PSA. ${ }^{28}$

\section{Conclusion}

President Putin has waged an attack on corruption on quite a wide front. At the same time, it is only possible to speak about the initial tendencies and first partial successes of a campaign that has just begun. In general, the struggle with corruption will be a long process, and it is impossible to defeat corruption at one stroke. Corruption can only be slowly, gradually, steadfastly reduced to a point where it is under control and at a level that does not threaten the security of the country. As a first step towards eliminating corruption in Russia, it is necessary to transform the country's whole socioeconomic base considerably, to "ennoble" what has become a parasitic and predatory bureaucratic capitalism. Under favorable circumstances, this will take some ten to twelve years. While the first step in this direction has been taken, this modest success has to be consolidated and developed, so that everything achieved does not once again "vanish in quicksand." On this path, President Putin will still have to overcome a number of serious difficulties.

First, it will be necessary to form his own joint team of reformers. As of today, the Government is not an organic member of such a team. Separate ministers

\footnotetext{
${ }^{27}$ See: Moskovsky Komsomolets, 9 February 2001; Segodnya, 25 January and 13 February 2001; Nezavisimaya Gazeta, 26 January 2001; Vremya Novostei, 19 April 2001; Vedomosti, 29 June and 20 July 2001.

${ }^{28}$ Nezavisimaya Gazeta, 18 May 2001; Vedomosti, 20 April and 23 August 2001.
} 
favor different approaches. Many of them are still serving the interests of various oligarchic groups, and this causes conflict with each other and even with the Prime Minister. The Prime Minister himself frequently drags out fulfillment of the President's orders or implements them according to his own interpretation.

In the future, Putin will have to take further steps in the gradual process of getting rid of the "inheritance" from the Family that previously occupied the office of President. Finally, under conditions where a mature civil society is lacking and, at the same time, there is a need to integrate the country into the wider international society of developed economies, Putin will have to solve a complicated dilemma. The implementation of "enlightened authoritarianism" inside the country-without which there is no chance to defeat bureaucratic capital and corruption-will have to be combined with supporting Russia's democratic image in the outside world. 


\section{Bibliography}

Blashi, Joseph R., Maya Kroumova, and Douglas Kruse. Kremlin Capitalism. The Privatisation of the Russian Economy. Ithaca: Cornell University Press, 1997.

N.A., Simonia. "On Bureaucratic capitalism in Russia." World Economy and International Relations (1996). 